\title{
Contingency in Jural Relations
}

Statement of the problem. The questions to be considered are: (a) the nature of contingency; (b) the kinds of contingency; (c) the effect of contingency on relations of fact as bearing on the problem whether such relations are or are not jural relations; and (d) the character of jural relations affected by contingency.

Nature of contingency. Contingency never can be predicated of any act, event, or relation either past or present; it is referable only to future acts, events, or relations. There is one proviso-that an existing relation whether jural or non-jural may be affected by future acts or events; an existing relation of fact may be denied present jural quality because of some future contingent act or event; an existing jural relation niay be denied present zygnomic ${ }^{2}$ character because of some future contingent act or event.

For example: A may expect, and have sound practical reasons for believing, that, if he makes a certain offer to B, B will accept the offer and thereby create a promissory obligation between $A$ and B. A has a jural power to make his offer, but this power is a simple power which may or may not be exercised; nevertheless, it is at present a jural relation despite the contingency, because the evolution of that relation lies solely in the control of $A$ who is

1 Relation is a fuuction of two things $\phi(X, Y)$. Thing is any entity which has a predicate.

Anomic relation is one which is not a legal relation. Example: B has accepted $A$ 's invitation to dinner.

Mesonomic relation is a legal relation which does not directly constrain. the servus of the relation (i) in his physical freedom, (ii) with the support of the law. Examples: power to make an offer; power to accept an offer; power to abandon a chattel; power to violate a contract duty; power to commit a tort.

Zygnomic relation is a legal relation which (i) directly constrains the servus of the relation in his physical freedom and (ii) with the support of the law. Examples: duty to respect another's corporal integrity; duty to perform an uncontingent contract promise; duty to pay damages for breach of a contract promise; power to eject a trespasser; privilege to enter land under an easement.

Each jural relation is constituted of (i) a dominus (the holder of a legal advantage), (ii) a servus (the bearer of the corresponding legal disadvantage), and (iii) an act which is involved in the relation. Example: if $\mathrm{B}$ owes $\mathrm{A} \$ 100, \mathrm{~A}$ is the dominns, B is the servins, and the act involved in the relation is a tender of $\$ 100$. The act is evolved when $\mathrm{B}$ makes an actual tender to $\mathrm{A}$ of $\$ 100$. The evolutive act of one legal relation may be the involutive fact of another legal relation. Thus, if $B$ makes an actual tender, $A$ then gets a power to accept the tender. B's actual tender is the evolutive act (evolution in the mathematical sense) of B's power to tender and it is also the involutive fact of A's power to accept the tender.

2 See, supra, $n 1$. 
the dominus ${ }^{3}$ of the power. The evolution is contingent but the contingency is in sole control of the dominus of the power.

Following the illustration, before A makes his offer, $\mathrm{B}$ does not have a present power of acceptance of an offer not yet made. B's power to accept depends on the evolution of A's power to offer. B's relation to $A$ before $A$ 's offer is not a jural relation; it is not even a mesonomic ${ }^{4}$ relation; it is purely an anomic ${ }^{5}$ relation until $\mathrm{A}$ makes his offer, when, in turn, B's power to accept arises as a mesonomic relation subject to the contingency of B's actual acceptance.

Going a step farther, no contract presently exists in any jural form, however practically certain that such a contract will be made. In the illustration put, there is presently only one jural relationthe power of $A$ to offer (and that relation is of the mesonomic order); the subsequent possible relations (the power to accept and the ensuing contract relation) are not yet in existence for any practical or legal purpose; they still rest upon the contingency that A may or may not make an offer.

Contingency, then, means uncertainty of happening (in the future) of some act or event. It does not affect the present existence of a relation. That relation may be jural or non-jural. The precise question is (i) how much and what kind of contingency can be admitted before a given relation of fact is excluded from the realm of jural relations, and (ii) if such relation despite contingency is accepted as a jural relation, how it shall be classified as mesonomic or zygnomic.

For example, where the defendant fired guns near trees owned by the plaintiff in which rooks were in the habit of nesting whereby plaintiff lost the profits that he might have gained in young rooks that probably would have been hatched, it was held the plaintiff could not recover. ${ }^{6}$ In another case, the defendant fired guns near the decoy pond of the plaintiff and frightened away wild fowl, and the plaintiff was permitted to recover. ${ }^{7}$ In both cases, there were relations of fact. There was no contingency in the existence of these relations, but in both cases there was contingency whether the factual interest would be realized. The cases noted are distinguishable, not in contingency but on the ground that in the first case rooks were by statute a public nuisance. The first relation

${ }^{3}$ See, supra, n. 1 .

4 Siee, supra, n. 1.

5 Siee, supra, n. 1.

6 Hannam v. Mockett (1824) 2 B. \& C. 934, 4 D. \& R. 518, 2 L. J. (O. S.)

K. B. 133, 26 Rev. Rep. 591, 107 Eng. Rep. R. 629.

7 Keeble v. Hickingill (1809) I1 East, 574, 103 Eng. Rep. R. 1127. 
(rook case) was non-jural, but not because of contingency, and the second relation (wild fowl) was jural in spite of contingency.

All jural relations involve contingency. Some relations of fact implicate contingency; others do not. A spatial relation or a relation of series or order does not implicate contingency. The relation exhausts itself by the mere fact of its existence. Jural relations, however, always implicate contingency because they invariably involve an act. The evolution of this act is always uncertain in all relations whether zygnomic or mesonomic.

For example: If A owes B $\$ 100$ to be paid on January first, the time is certain, but the evolution of the debt relation is entirely uncertain. There is no certainty that A will pay or will fail to pay his debt. The continued existence of the relation to the evolutive date also is uncertain. Either or both of the parties to the relation may die, the debt may be novated, and in various other ways, unnecessary here to be enumerated, the debt relation may be terminated or its legal character may be changed. Notwithstanding the contingency, the relation is zygnomic.

Again, if $\mathrm{D}$ has a power of appointment at discretion to one or more of the heirs of $\mathrm{A}$ of land held in trust by $\mathrm{C}$, there is the highest form of contingency in the power relation. There is no certainty that $D$ at any time will exercise his power of appointment. Yet, D's power is a legal relation; there is no contingency in his power; the only contingency is in his exercise of it. However, no one of the persons of the class in whose favor the power may be exercised, sustains any legal relation connected with the power. These persons have only a bare factual interest or possibility of becoming owners of the land. There is a practical distinction recognized by the law in the realization of a factual interest which depends on the activity of another person for the realization of such factual interest. Whether the owner of a decoy pond will act to obtain the wild fowl attracted to his pond, depends solely on the owner. The law regards that interest as something more than a bare possibility. But in the power of appointment illustration, the possible owners cannot control the contingency.

Kinds of contingency. The elements to which contingency attaches are the factors that create, alter, or extinguish jural relations. There are only two such elements-acts (the results flowing from human conduct) and events (all other jural occurrences). These acts or events are always connected with persons but the event or act is always the significant element for juristic consideration in connection with contingency. If the contingent fact is 
that A shall die leaving children surviving him, the survival of children is the fact of primary importance and their identity is secondiry.

In a consideration of the contingency of acts and events, there also may be uncertainty (a) in the nature of the act or event, (b) in the place of the act or event, (c) in the manner of occurrence of the act or event, and (d) in the time of occurrence of the act or event. Of these forms of contingency, the last one is of chiefest importance-the time of occurrence of the act or event. Thus, if an estate is devised to $A$ for life with remainder to the eldest son of $B$, the chief factor of contingency is one of time. If $B$ presently has no son, the remainder is purely contingent. The elements of the nature of the event (the birth of B's son), of the manner of his birth (whether deformed or not), and of the place of his birth are already defined either by the will, by rules of law, or both, or are imrnaterial. The significant fact is the birth of B's son before the terraination of the life estate. If B's son is born after the termination of the life estate, the remainder fails. The time element, therefore, is the chief one.

\section{A. Temporat Contingency}

Certainty and uncertainty. Contingency of time of acts or events as opposed to acts or events certain to happen at a fixed time (e.g., an eclipse) (dies certus an et quando) are:

(1) Occurrences certain to happen at a time unknown. Example: death of a given human being (dies certus an incertus quando).

(2) Occurrences uncertain to happen at any time. Example: death of A leaving children surviving (dies incertus an incertus quando).

Internal and external contingency. Contingency may affect a relation in two ways: (a) by an occurrence having an internal connection with the content (act) of a relation; (b) by an occurrence affecting a given relation from the outside. Whether a duty will be performed or whether a power will be exercised is a matter of internal contingency. Whether a condition precedent or subsequent slrall be performed, or whether an event shall happen, is external contingency. Thus, the contingency that $\mathrm{B}$ has a son in the lifetime of A may determine the disposition of a remainder in land.

The evolution or devolution of one relation may be a fact external to another relation. Thus, a tenant may owe a duty not to commit waste. The breach of this duty (devolution) is a fact external 
to the creation of a nexal power to forfeit the lease. Before the devolution of the tenant's duty, the landlord's power was a mesonomic relation; it could not then be exercised but it could be assigned with the land as an accessory right. After devolution, the power became zygnomic.

Contingency, therefore, may exist: (a) as to the evolution of a jural relation; (b) as to the continued existence of a jural relation connected with an external fact (e.g., condition subsequent); and (c) as to a change in jural character of a relation (e.g., transformation of anomic relations into nomic ${ }^{8}$ relations and in reverse, or transformation of mesonomic into zygnomic relations and in reverse).

Simple and complex contingency. Simple contingency is contingency of occurrence of an act or event uncomplicated by reference to another act or event itself contingent. Examples: Will $\mathrm{A}$ live until 1950? Will S pay his debt when it is due? Will D exercise his power of appointment? Will $\mathrm{D}$ accept an offer made to him?

Complex contingency is contingency of occurrence of an act or event by reference to another act or event itself contingent. The fact of reference may be an occurrence certain to happen at a time uncertain or an occurrence uncertain to happen at any time. Examples: Will A survive B? A devise to the child first born to $B$, an unmarried man. Remainder to $B$ provided $B$ marries $C$ : two contingent facts, because marriage involves offer and acceptance. Will $B$ accept an offer if A makes it?

Lineal and collateral contingency. Lineal contingency is made up of factors which succeed each other in point of time. Lineal contingency may be simple or complex. Examples: grant to $A$ and his heirs until $\mathrm{B}$ comes back from a voyage and then to $\mathrm{C}$; this is a conditional limitation and involves simple lineal contingency. Devise to $A$ in fee with power to $B$ to appoint in fee; this is a condition subsequent and also involves simple lineal contingency. Limitation to $A$, an unmarried man, for life, remainder to A's son by marriage to $\mathrm{B}$; this is a complex lineal contingency.

Collateral contingency is made up of coexisting factors, present or future, and the determination of one of these factors before the other. It may be simple or complex. Examples: limitation to A for life, remainder to $B$ for life, and if $B$ dies before $A$, remainder to $C$ for life. This example involves both simple and complex collateral contingency. As between $A$ and $B$, the contingency is collateral but simple; if $\mathrm{B}$ dies before A, B's estate never falls in;

${ }^{8}$ See, supra, n. 1. 
if $B$ survives $A, B$ takes the remainder and $C$ takes nothing. As between $B$ and $C$ the contingency is also collateral but complex, since before $\mathrm{C}$ can take the remainder, $\mathrm{B}$ must predecease $\mathrm{A}$ and $\mathrm{C}$ must survive $\mathrm{A}$.

Vested and contingent remainders. The terminology for these ideas is not especially forturiate. All remainders are said to be estates in expectancy. A reversion, on the other hand, while commonly designated an estate in expectancy is not strictly in expectancy; it is a fresently existing title which for the time being is incumbered; it is not a case, nor can it be, of something cut out of an estate later to be restored to its full compass; the true situation is one of conflicting rights ' where the original right is temporarily overshadowed by a later right; when the later right comes to an end, the conflict is removed, and the original right stands unincumbered.

Where a remainder is created, a particular estate is given or reserved to one person and at the same time an estate expectant in right of possession concerning the same res is given to another person. A remainder is never strictly an expectant estate; it is already an existing title even though purely contingent as to the person who is to enjoy it. A reversion also is an existing estate. The difference between a reversion and a remainder is simply in the nature of two kinds of conflicting rights. In a reversion, the original right is occluded or incumbered by a right later created, as for example where $A$, the owner of the fee, grants a term for years to $B$. Here the fee is incumbered (not cut up) by the term. In a remainder, the particular estate, so-called, is an incumbrance on the ultimate estate (the remainder). The remainder is not an estate in expectancy; it is a presently existing estate subject to a present incumbrance, and in all cases it is subject to contingency of enjoyment even in those cases where the remainder is denominated as "vested".

The juristic situation as to reversions and remainders may be illustrated by the following diagram:
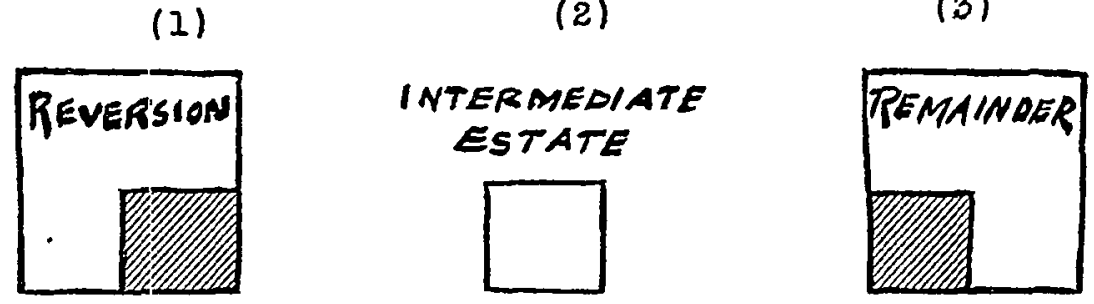
Explanation: The intermediate estate, whatever its compass, is an incumbrance upon ownership. In the case of reversion, the intermediate estate in point of time of enjoyment follows ownership. In the case of remainder, the intermediate estate in point of time of enjoyment precedes ownership. In both cases, the intermediate estate is a cloud on ownership. When the intermediate estate ends, this cloud on the ownership is removed. In neither case, is ownership in the slightest way diminished (cut down). The reversioner and the remainderman remain owners throughout.

There is still a further distinction which is purely a practical one based on the practice of conveyancing, that only one reversion is created where a lesser estate is created, while where a particular estate is created, more than one remainder can be and often is created. However, theoretically, and practically also, it could be otherwise. Where a lesser estate is created, the grantor might reserve to himself and to others a series of reversions upon the same terms as remainders are commonly created.

That the term "vested" is purely an artificial one and depends on certain arbitrary rules. is easily shown. If a term is granted to A for 999 years with remainder to B for life, B's remainder is said to be "vested", although clearly there is no possibility of B's enjoyment of his estate except upon the contingency that A forfeits his term. The artificiality of the term is also shown by the somewhat curious fact that there may be a series of "contingent" remainders followed by a "vested" remainder. Whether the remainder is "vested" or contingent is in no way affected by contingency of enjoyment in possession.

A remainder is said to be "vested" if the donee is in esse and is certain to come into possession if he lives long enough or if he would immediately come into possession upon a contingent determination of the particular estate. It is clear that a "vested" remainder is just as contingent in enjoyment as a so-called contingent remainder. The rules governing the matter are purely feudal and have their basis in the external purpose of insuring the performance, as far as possible, of feudal services. There must always be an existing tenant for whose benefit a livery of seizin could be effected. Thus, an estate for years would not support a contingent freehold remainder. The artificial rules governing remainders did not apply to executory devises and they no longer fit the conditions of modern life.

In a word, the whole body of learning governing "vested" and "contingent" remainders lies apart from the idea of contingency in 
a theoretical sense. A "vested" remainder juristically is always a contingent remainder and a "contingent" remainder is always a vested remainder. This, of course, is not to deny that there are important legal differences.

By the feudal rule, the remainder must pass out of the grantor at the same time the particular estate is created. If the remainder was contingent, let us say because the donee was not in esse when the frarticular estate was created, who was the owner of the remainier?' It had passed out of the grantor and the donee was not in essie. The feudal theory could give no better answer than that it was "in gremio legis", but there is no theoretical difficulty in supposing that the remainder was already vested in a juristic sense in the legal persona of the contingent and still unborn donee, subject to revert upon the non-happening of the contingency, to the grantor or some other person.

\section{B. Fields of Contingency}

Some of the chief fields in which contingency operates are set out in the following enumeration.

Existing duties or powers. There is always contingency whether a given duty will be performed or a power exercised. The fact of contingency in these cases does not prevent the recognition of them as legal relations. This is true even though, for example, the duty be non-enforcible (e.g., executory promise of a minor) or that the powes: be merely preliminary to other legal relations (e. g., power to make an offer). If jurality were demied to duties and powers because of contingency, then all legal relations would become impossible. The real problem, however, is what line if any is drawn before a given act will be recognized as a duty or power. The short answer seems to be that once an interest is regarded as deserving of protection no line will be drawn against its protection because of contirgency of realization of the interest in individual cases, although if, in general, an interest could not be protected because duties would be generally disregarded or powers be generally not exigible, the policy of the law would wisely refrain from attempting the impossible. For example, if promises were generally disregarded or certain kinds of trespasses were practically inevitable, the law would find the burden of protection too difficult for practical realization.

Where the law recognizes given duties and powers they are protected not only as against the $s e r v i^{9}$ of these relations, but the rela-

9 S.ee, supra, n. 1. 
tions themselves are protected as distinct legal interests against unjustifiable interference by third persons. Thus, it is a matter of contingency whether $A$ will carry out his promise to $B$, yet $C$ may not by fraud determine the contingency against $B$ by causing $A$. to move contrary to his duty.

Where a duty is created by contract and is broken, the value of the duty will be measured if possible even where the value at the time of breach depends on contingency. Thus, where a whaling master is wrongfully discharged, he may recover his share of the profits of the voyage. ${ }^{10}$

Appurtenant power of gain. This contingency of gain presents itself in two chief forms: (a) gains appurtenant to a business requiring acts of the public; (b) gains appurtenant to ownership of a thing requiring acts of the owner for the realization of the gain. In both of these cases, the contingency may be very great, but yet the law affords protection to the prospective gain if there is any measure by which the probability of gain can be reasonably estimated. What is contingent is treated as certain to happen if there is a measure of experience and if the loss is not too remote. Thus, if a tenant is wrongfully ejected from premises by his landlord, the tenant may recover for loss of profits based on the experience of the business. But if a fisherman sues because of damage done to a fishing net, he may not recover for loss of profits. ${ }^{11}$

Appurtenant powers of gain when connected with a business enterprise are also protected against unfair competition, infringement of trade marks, and defamation of goods.

Non-appurtenant power of gain. Where a contingency of gain is not connected with a contract duty, or a business, profession, or occupation, or with land or chattels, and requires an act to realize the gain, the contingency as a rule has no protection. A hunter has no protection in his contingency of capturing wild game, but if he succeeds in depriving a wild animal of its natural power of escape and continues the pursuit, he will be protected as owner against another who first takes the animal. ${ }^{12}$ The Roman law rule was stricter, requiring actual detention of the animal before ownership was created. Where fish are partially inclosed in a mechanical net, on the contrary, it has been held to be larceny to take the fish, even though there remained the contingency that the identical fish taken

10 Dennis v. Maxfield (1865) 10 Allen (Mass.) 138.

11 Wright v. Mulvaney (1890) 78 Wis. 89, 46 N. W. 1045, 23 Am. St. Rep. 393, 9 L. R. A. 807 n.

12 Pierson v. Post (1805) 3 Caines (N. Y.) 175, 2 Am. Dec. 264. 
might have escaped. ${ }^{13}$ Likewise, disturbing fish partially inclosed in a net operated by hand is not an infringement, of a right of ownership in the fish, but is a breach of duty not to interfere with a power of gain. ${ }^{14}$ The distinctions in these cases are based on the practical proximateness of control. That power of control may be either ownership or the right to become owner.

Grants of future contingent enjoyment. This field is chiefly occupied by "vested" and "contingent" remainders and executory devises. They create actual legal relations, but there are differences in the collateral legal relations that arise with them. A "vested" remainder may be devised, granted, or limited over, and it may be made the basis of "contingent" remainders and trusts. Contingent remainders not involving uncertainty in the identity of the donee may now be assigned or devised, but a contingent remainderman may not at common law, however, have a remedy to protect his interest before the contingency happens.

The contingency of actual enjoyment of the estate in these instances may be very great, but yet the law allows the creation of present estates contingent in enjoyment limited only by the rules against remoteness because they flow from a pre-existing right of ownership. There is an evident distinction between the creation of a new and underived right of ownership based on contingency and a right of ownership derived from a pre-existing right of ownership based on contingency of enjoyment. One can not ordinarily become the cwner of fish in the sea until he overcomes the contingency of capturing them. There is nothing here to be assigned or devised; in all respects the relation of a person to any res nullius is practically without legal significance, although each person has a simple power to become owner if he can. There would obviously be no need of permitting a power of assignment or of devise in such a case, because each one already has all that could be assigned or devised.

Going a step farther, a right of entry upon a condition subsequent which has not yet happened, or a possibility of reverter, are descendible but they may not be assigned. Whatever may be the underlying reason (various reasons are given) for the policy of the law in these cases, the situation is a different one from that presented by a contingent remainder. A contingent remainder moves forward from a pre-existing ownership. It is something that the

${ }^{13}$ State v. Shaw (1902) 67 Ohio St. 157, 65 N. E. 875, 60 L. R. A. 481. R. 228.

14 Young v. Hichens (1844) 6 Q. B. 606, D. \& M. 592, 115 Eng. Rep. 
pre-existing owner creates for the benefit of another. But a power of entry for condition broken, or a possibility of reverter, is a legal advantage which an owner creates for himself or which the law creates for him; it is retrospective in operation as against the owner of the existing estate. The variance of rule corresponds with a variance in the jural situation; there is a practical difference sufficient to account for the difference in the rules.

Reversionary interests. These interests have already been partially discussed. Reversionary interests are of two classes: (a) interests based on contingency (e.g., possibility of reverter); (b) interests not based on contingency. A landlord's reversion may be contingent or non-contingent. If there is a term of years, the reversion is not contingent, but if the term is for an uncertain period (e. $g$., life of the tenant or at will), it is based on a contingency. The term "reversion" here is apt to be somewhat misleading. What accurately is meant by "reversion" is not that some legal estate "reverts" or goes back to the landlord, but that an incumbrance on the landlord's ownership ceases. The landlord's ownership was not diminished (cut down) by the term, nor was it enlarged by the ending of the term. It remains throughout the same ownership but its jural character has been altered. Where a possibility of reverter is realized, there is accurately a reversion (going back) of the title to the grantor or to his heirs.

Future contract rights. Interests resting on the performance of promises form one of the most important fields of contingency. Where a promise is made there is contingency of performance, but if the promise meets the positive and negative tests of what constitutes a valid contract, there is no restriction on what may be turned into a promissory legal relation. It is easy to see why contingency is admissible in these cases; promises are in effect only exchanges of deferred economic advantages. Modern economic life could not dispense with this institution. All jural relations without exception, and most conspicuously those involving an appreciable element of time, are based on contingency of evolution (internal contingency).

Promissory obligations also may be based on external contingency. Promises may be made contingent:

(a) Upon the performance of another's naked promise (anomic relation). Example: A makes a promise to $\mathrm{B}$ contingent on C's promising to make a gift to $A$.

(b) Upon another's unenforcible promise (mesonomic relation). Example: A makes a promise to $B$ contingent on C's payment to A of a debt barred by limitation. 
(c) Upon another's enforcible promise (zygnomic relation). Example: A makes a promise to $B$ contingent on $C$ 's payment of his debt to $\mathrm{A}$.

(d) Upon an event uncertain to happen. Example: A's promise to $B$ contingent on C's return from Paris.

(e) Upon an act (not a part of the promise) uncertain to happen. Example: A's promise to B contingent on C's approval.

From the standpoint of legal rules, these instances present no practical difficulty. Unless other affirmative elements are intruded, there is no reason to doubt that in each of them, upon the happening of the contingency, the duty of performance will be complete. These instances, however, show the effect of contingency in giving jural character to legal relations. Since the duty in each of these cases is contingent upon an external act or event wholly uncertain to occur, the jural relations are mesonomic. They are not converted into zygnomic relations until the contingency happens. Internal contingency does not affect the character of jural relations.

Future contract rights exceptionally also may be assigned. For example, wages to be earned in the future in an existing employment determinable at will may be assigned. The rationale of this rule is analogous to the rule of the sale of a potential interest. ${ }^{15}$ The wage earner already has a potential factual interest in the future wages, although this interest is now contingent in enjoyment. A similar: assignment of future wages under a future employment would be invalid. The basis of these rules lies solely in the proximateness of realization of an expectancy. The problem here is not one of juristic logic but of practical expediency. In general, courts of law do not favor transactions based on external contingency. Courts of equity, on the contrary, favor contingent transactions and leave to parties the widest freedom in the making of agreements based on contingent interests. This is practically effected by means of a bold but convenient fiction. An equitable "assignment" socalled creates an equitable right especially in security transactions. ${ }^{10}$

There is no analytical difficulty in dealing with a potential interest as a thing to be assigned or mortgaged. If an owner of land mortgages a crop to be raised on his land from seed not yet planted or even bought, there is already a potentiality which is an ideal thing. If seed is planted and is already germinating, the nature of the thing has not yet changed-it is still an ideal thing and it remains such

15 Grantham v. Hawley, Hobart 132, 80 Eng. Rep. R. 281.

16 Holroyd v. Marshall (1861) $10 \mathrm{H}$. L. Cas. 191, 33 L. J. Ch. 193, 9 Jur. (N. S.) 213, 7 L. T. 172, 11 Eng. Rep. R. 999. 
until the occurrence of a condition precedent, the development of something that meets the description of the potentiality in economic realization, when the ideality of the thing is transformed into a material object. In general, the law does not favor a dealing with potentialities unless connected with a material object through which the potentiality may be realized in economic form, and the preponderance of judicial view requires even something more than that-a physical connection with a material object that will in the course of nature produce an economic result. The difficulty of dealing with potential interests either by contract or as things to be sold is not one of logic but of practice. There are clear reasons why there are exceptions in contract law to the general rule and a benevolent liberality in equity as against the restrictions at law in dealing with contingent interests that ripen into material objects. The chief reason is this: the rule of bona fide purchaser for value is not in general applied to chattels. It would be highly disturbing to society if a new element of insecurity were introduced in dealings concerning chattels. Such uncertainties threaten everyone and the law refuses the stamp of jural relationship to such situations involving contingency, not in any sense because of contingency itself, but because of the legal effects that would flow in the distribution of legal relations affecting, as a rule, many other persons. In contract rights and equitable rights, on the contrary, only two persons are directly concerned with the contingency of the transaction, and where third persons are also concerned, the element of want of notice is a sufficient safeguard against the uncertainty introduced by contingent transactions. The resulting distinctions, therefore, are like a parallelogram of forces; they are the direct product of other legal rules; and the result tends to be one which protects the security of commercial dealing.

Future gains conditioned on the act of another. Any person may entertain the hope of being the donee of a gift inter vivos or under a will. Such an expectancy, however proximate but yet falling short of an actual offer or a will followed by death, is not a legal interest. It may, however, be the basis of an equitable "assignment". There is a general tendency to deny legal relationship to factual relations not admitted as contractual, where realization depends on the act of another. Expectancies dependent on acts of another are comparable in idea to an independent intervening cause in civil and criminal liability. A human intervention causes a break in the causal chain and results in the negation of liability. An expectancy dependent on a human intervener negatives the creation of a legal 
interest. This has been carried to the extent of denying liability of a third person who interferes with such an expectancy; thus, if a third person induces the testator to alter his will in favor of a given beneficiary, it has been held that there is no liability. The question here again is one of legal policy and not of juristic logic. Juristically there is no reason why an expectancy of this kind may not be: assigned and protected from unjustifiable interference in the same way that a future crop may be assigned. The chief practical difficulty lies in the uncertainty introduced by the recognition of such interests. If unjustifiable interference in such instances were made actionable, what certain measure of damages could be applied? The question suggests not an addition to the law of assignable expectancie; or a change in the rule of damages, but rather a supplement to the scope of qui tam actions which in modern law have taken the place of the "actiones famosae" of Roman law.

Future property rights dependent on events. Property rights created by grant and contingent for economic realization on acts or events have already been touched upon. We consider now similar rights contingent on events. The instance of potentialities, which under divergent applications in their scope have found legal recognition, has been briefly noticed. It is clear that contingency of realization of an interest dependent on an event is not in legal policy objectionable. Two instances similar in contingency but variant in legal result may here be considered as typieal examples. These instances are inchoate dower and expectant heirship.

Inchoate expectancy of dower presents complex collateral contingency-the contingency that the husband will die leaving his wife surviving. The contingency is double. The wife or the husband may die first. Put in the form "the husband shall die leaving his wife surviving", it is seen to be the highest form of contingency. If the wife predeceases the husband, no interest passes to her heirs. In the life of her husband, she may not make an assignment of her interest. The husband can effectually convey the land in the life of the wife, and if the wife predeceases the husband, the grantee's interest will stand unburdened.

The prospective heir will become "heres verus" if he lives longer than his father. Here also there is complex collateral contingency.

The two cases are identieal in contingency but different in legal result. There can be no doubt that expectant dower is a present legal interest. There must be a release of inchoate expectancy of dower to escape the contingency of its becoming realized or vested as an interest in land. It may be noticed at this point that inchoate 
expectancy of dower is an entirely different right from the right of dower. Inchoate expectancy of dower is not directly an interest in land. This expectancy is protected by remedies against fraud. When the expectancy of dower is realized, an entirely new right is created.

The prospective heir, on the contrary, while standing in precisely the same degree of contingency to the realization of his expectancy as the wife of a landowner, has no present legal interest. This variance in legal result is not, therefore, due to any difference in the logical structure of two factual relations, but rests on the accidents of legal history and the dictates of policy. Before the Norman conquest lands were devisable, but dower was unknown in Saxon times. With the introduction of the feudal system, restrictions were imposed on the power of devising lands so that in general no will was permitted until the reign of Henry VIII. At one period of our legal history, the son needed no protection since necessarily the inheritance would fall to him if he survived. With power of free alienation by will in modern times, the son's interest has ceased to be protected either directly (as by the légitime of Roman law countries) or indirectly as by withdrawal of the power of devise. The expectant heir's interest is not one that can be assigned and in Roman law a contract made by an heir apparent to convey his inheritance was void. ${ }^{27}$

Meaning of the termis "possibility", "inchoate" right, and "vested" right. We have seen that there are two forms of contingencyinternal contingency and external contingency. Internal contingency (i. e., of evolution) is a characteristic of all jural relations. External contingency attaches to jural relations whose economic realization depends on an act or event collateral to such jural relations. This distinction furnishes the key for the proper distribution of terms to denote the existence or absence of contingency.

Possibilities. Usage here is not uniform. There are two applications in current speech: (a) that a "possibility" is a relation of fact which may be followed by a jural relation. Thus, it is possible that A may make a gift to B. Again, it is possible that $\mathrm{C}$ may make a contract with $D$. In these instances, there is no present legal relation, but there are anomic relations which by chance may ripen into nomic relations. No degree of probability or practical certainty that $A$ will make a gift to $B$ creates in $B$ any legal interest either in the hope of the gift or in the object of the gift. No degree of probability that $C$ will make a contract with $D$ creates a con-

${ }^{17}$ C. 2.3.30; D. 28.6.2.2; Ent. d. Rg. in Civilsachen IV 36. 
tractual legal relation or even a legal interest in the expectation of a contract.

(b) Sometimes the term "possibility" is applied to an actual legal relation which involves a high degree of external contingency. Coke stated as an established maxim that no possibility, right, or thing not in possession or vested in right could be granted or assigned. ${ }^{18}$ Examples of this usage are possibilities of reverter and powers to defeat a freehold granted to another upon failure to perforin a condition.

It is impossible to harmonize these different applications or to construct a logical concept of "possibility" based upon them. It is believed that the preferable solution is to restrict the application to the first usage-an expectation not recognized as a legal interest. In that sense, a "possibility" of reverter is something more than a "possibility"; it is a present legal claim but a contingent one. It would be desirable to denominate it simply as a right of reverter.

Inchoate rights. Inchoate rights are contingent legal relations based on an expectancy. A prospective heir has an expectancy but his hope is not recognized as a legal relation. A wife lias an expectancy of outliving her husband and taking a dower interest in his land. This expectancy is a legal interest. The power to make an offer is not an inchoate right of contract. This power is not an expectancy and there is no external contingency connected with it. Likewise, the power to accept an offer is not an inchoate contract. Here, again, the power is not subject to external contingency. Going a step farther, a contract relation is not an inchoate right; it is not an expectancy of a contract but is already a contract. It may be said, perhaps, that there is an expectancy of economic enjoyment of the performance of the contract, e.g. the payment of money. There is no doubt such an expectancy from a lay point of view, but from a juristic standpoint the claim to a performance is not an "expectancy" of the performance but the right to have it. The wife's expectancy of dower is not a claim to dower but a claim against interference with the hope of getting it. The power to commit a tort is not an inchoate claim in another to have compensation; nor is the power to violate a contract duty an inchoate claim to darnages. The hope of gaining a crop after planting seed is not an inchoate right to the crop but the hope itself is an inchoate right.

The term "inchoate" as applied to rights is one of considerable difficulty. The dower illustration may again be employed to demonstrate the point. There are three possible views of the matter:

181.0 Coke on Littleton, $265 \mathrm{a}$, note 212 . 
(1) That the wife of a living husband has only an expectancy of dower; that there is no dower right (i.e. no claim to an interest in land based on a contingency); that, accordingly, there is no inchoate right of dower; but that the expectancy of dower is an inchoate right simply because it is an expectancy only (i.e. an interest not realized).

(2) That the expectancy of dower and the contingent interest of dower are two distinct rights; that the hope of dower is one right (a complete right since a hope can not be more complete than itself and since the existence of the hope is not based on contingency) and that right of dower based on contingency is another distinct right; that the hope of dower is not inchoate but that the contingent right of dower is inchoate.

(3) That the expectancy of dower and the contingent right of dower are not two legal relations but only' one legal relation; and that this single contingent right is an inchoate right.

Of these three views, the first seems to be the correct one. When the wife in the lifetime of her husband "releases her dower", she releases simply the expectancy of getting dower; she can not presently release the dower itself.

There does not seem to be any clearly defined or accepted meaning of the term "inchoate". Various meanings are possible. The idea back of the term is a legal interest (i. e., not a mere possibility) as yet unrealized and depending for its realization on external contingency. This natural signification is easily understood and it would be convenient in application.

Illustrations of the application of the term "inchoate". If money is due under a contract, there is no inchoate right in the money. Payment may be made in any form of legal tender, and there can be no present legal interest in any particular coins or other form of money. Even if the duty is to transfer title to ascertained goods, there is no present legal interest in the goods. The element of contingency (performance) is present, but it is an internal contingency and there is also wanting a present legal interest in the result of the performance.

Inchoate rights are not "incomplete rights." Sometimes a right may not be assignable, or devisable, or inheritable, or leviable. Expectancy of dower has all of these negative qualities, and yet it is a complete, though inchoate, right; it is a present legal interest which is not yet fully realized in its economic or legal definition; and it is subject to complex external contingency. Expectant dower is a complete right, as much so as the right of dower. Expectant dower 
is not an incompleted ownership; indeed, it is not ownership at all of any legal interest in land.

Other instances of inchoate rights are power of re-entry before condition broken, lucrum cessans (future gains), hope of a future crop, expectancy of future wages in a determinable present employment, right of reverter, expectancy of homestead, unenforcible. promises, and dependent concurrent promises. For example, the executory promise of a minor is not enforcible unless he ratifies after majority. The full economic and legal value of the promise as promise is not realized until an act, externally contingent, (ratification after majority) occurs.

The limits of the present use of the term are realization in legal or economic scope of a legal interest on one side and the absence of a present legal interest on the other side. All that falls between belongs to the field of inchoate rights. An inchoate right, therefore, implies a present right which in its description defines a legal relation into which upon external contingency it merges by way of substitution.

Vested rights. The term "vested" is commonly opposed to "contingent" or to "inchoate", and sometimes it is opposed to a "possibility". It is not yet a term of juristic art; it lacks scientific precision. It hardly needs to be remarked that all rights are vested in the sense that they exist. Since the term is not one that qualifies the present existence of rights, it seems proper to limit its application in a juristic sense in opposition to the term "inchoate" as already defined.

\section{Summary}

The foregoing discussion may be summarized in the following propositions :

Contingency as such is not a test of jurality. All legal relations without exception are subject to internal contingency (i.e., evolution).

Whether a factual relation will be elevated to the plane of a jural relationship and whether a jural relation is a mesonomic relation or a zygnomic relation are determined by external contingency (i.e., an act or event external to the given relation).

Whether a bare factual interest is regarded as the basis of a legal relation depends in general on the power of control of the holder of the interest or the economic realization of the interest. The question is one of practical proximateness of control. 
If a legal relation is admitted, no extent of contingency in its evolution or in the realization of the economic advantage which it protects justifies external interference with it by socially unfair acts.

In polarized jural relations unlimited scope is allowed in the creation of promissary obligations based on external contingency, and in equity by the fiction of "equitable assignment" similar scope is allowed to effect the creation of contingent factual interests after the contingency occurs.

A vested legal relation, if assignable, can be assigned with unlimited contingency subject only to the rules governing remoteness.

Rarely, absolute uncertainty not affected by any power of control in the dominus of a factual interest is made the basis of a legal relation on grounds of public policy (e.g., expectant dower and homestead).

The rule of proximateness of control which expresses the individual interest is dominated by the social principle of security of transactions in factual interests contingent in economic realization.

All jural relations which are affected by external contingency in their constraining force are mesonomic, and those jural relations not affected by external contingency in their constraining force are zygnomic. Thus, all inchoate rights are mesonomic relations. ${ }^{19}$

Northwestern University School of Law,

Albert Kocourek.

Chicago, Illinois.

19 The scope of mesonomic relations, of course, is broader than that of inchoate rights. 